DISCURSOS E CONFERENCIAS.

\title{
A pedra fundamental da nova Faculdade de Direito na Cidade Universitária.
}

\author{
José Pinto Antunes \\ Diretor da Faculdade de Direito da Univer- \\ sidade de São Paulo e Catedrático de \\ Economia Política na mesma Faculaade.
}

À moda da rudeza bandeirante, a velha Academia do Largo de São Francisco não veio aqui para receber, mas para dar, para doar, para continuar a servir.

Recordemos a história que tivemos a honra de testemunhar como Deputado, que fomos, à Assembléia Constituinte de São Paulo, nos idos de 1934.

Quando Armando de Sales Oliveira projetava esta Universidade, pôs uma condição preliminar no genial planejamento. Não começaria, desde então, a Universidade, mas devera voltar no tempo para mostrar ao Brasil e ao mundo que a cultura paulista já vinha, desde 11 de agosto de 1827, plasmando a grandeza nacional. E, assim, devera a Faculdade de Direito, do Largo de São Francisco, constituir a célula mãe da nova Instituição que o grande estadista sonhava. Não resistiu an apelo, pela argumentação, a douta Congregação e, por isso, a Universidade, que começava a se desdobrar nestas paragens, via a sua história voltada para mais de um século de grandeza, pois a São Francisco, desde 1827, vem escrevendo, pela sabedoria de seus filhos, a história do Império e da República.

* Discurso proferido aos 30 de outubro de 1973 , no ato solene de lançamento da pedra fundamental do novo edifício da Faculdade de Direito, a ser erigido na Cidade Universitária Armando de Sales Oliveira. 
De fato, ela informou, com feição própria, a estrutura jurídica do Estado nascente. Consolidou o Império. Humanizou-o, fazendo a abolição da escravatura. Depois, à moda do tempo, derrubou o Império e fez a República. Repetiu os bandeirantes, ampliando, pela diplomacia do Barão do Rio Branco, os lindes da Pátria. embora já imensa.

Deu ao Brasil dez dos seus filhos para Presidentes da República. Assim, fez, consolidou e aperfeiçoou a República brasileira.

Rui Barbosa, o maior entre os maiores dos seus filhos, ensina continuadamente a mocidade do Brasil a respeitar e defender os direitos individuais da liberdade e mesmo a se revoltarem, como em 1932, quando eles são conspurcados pelas ditaduras.

Magnífico Reitor.

Meus Senhores.

Não estamos aqui para ler a história do Brasil qque a Academia do Largo de São Francisco vem fazendo há perto de século e meio.

Recordamos, em ligeiras lembranças, o seu grande patrìmônio, para confirmar a nossa afirmação inicial de que "viemos aqui para dar e não para pedir".

A São Francisco, está, aqui, pelo seu Diretor, para tomar conhecimento do marco histórico, em que, com o seu nome, lembrará a todos que esta Universidade nasceu a 11 de agosto de 1827, no Sagrado Largo de São Francisco, como desejava que fosse o seu grande fundador, Armando de Sales Oliveira.

E nesse descampado espalhamos, com aquela munificência paulista, os 150 anos de grandeza da nossa velha, mas sempre nova Academia. São estas as reais pedras fundamentais que doamos e plantamos nesse ato solene de posse a que fomos convidados. 
Não é pois, ali ao lado, Magnífico Reitor, o centro da Universidade que Vossa Magnificência tão sabiamente dirige; ali, temos, simplesmente, o ponto central desta uni dade arquitetônica, mas, aqui, na sede do novo edifício, é que se erguerá o seu centro histórico, onde, solenemente, hoje, depositamos, em recordação, a história da Faculdade de Direito do Largo de São Francisco, que há 150 anos se confunde com a própria história de São Paulo e do Brasil.

Perdoem-me VV.Excias. a retificação do "nomen juris" deste ato solene.

Não recebemos, porque estamos doando ou melhor, ratificando uma doação.

Não se trata de ato jurídico que se qualifique entre as espécies contratuais do "do ut des", "do ut facias", "facia ut facias", porque a nossa doação é sem recíproca.

É um ato de amor, é um ato cristão de sacrifício...

"La charité tue le droit".

E, assim, Magnífico Reitor, como ato de amor por esta Universidade é que recebemos hoje este descampado onde se plantará o marco da grandeza da velha "Academia da Cidade de São Paulo".

Neste sentido, Magnífico Reitor, muito obrigado ern nome do Corpo docente, discente e administrativo da minha, da sua, da nossa querida Faculdade que já se sente bem em se denominar, quase orgulhosa, "Faculdade de Direito da Universidade de São Paulo". 